\title{
mabalnanecessärio
}

issn: $1808-799 \mathrm{X}$

ano 4 - número 4 - 2006

\section{JOVENS POBRES E A EDUCAÇÃO PROFISSIONAL NO CONTEXTO HISTÓRICO BRASILEIRO}

Denise Cordeiro*

Eduardo Antônio de Pontes Costa*

\section{INTRODUÇÃO}

Em toda discussão que se pretenda produzir sobre a educação, deve-se ter como pressuposto as condições econômicas, políticas e sociais de um país. Quando essa mesma discussão enfoca a juventude[1], as especificidades suscitam um olhar cauteloso notadamente quando o eixo de análise busca situar os jovens pobres na relação entre trabalho e educação.

A juventude é uma etapa de vida entendida como uma produção histórica, que existe como experiência do seu tempo, como expressão de relações sociais e culturais. Para além desses paradigmas, é preciso entender que não há apenas uma juventude, mas várias, que vivem a condição de ser jovem não somente do ponto de vista biológico, mas de caráter simbólico. Peralva (1997) afirma que as sociedades contemporâneas, especialmente para aquelas onde há maior distribuição de renda per capita, adiam o ingresso do jovem no mundo do trabalho e ampliam os lastro da escolarização, o que contribui para construir um modelo cultural da juventude. Essa tensão entre ciclos da vida e inserção nos modelos estruturais da sociedade, entre a juventude como categoria geracional e como sujeito que expressa uma diversidade precisa ser eqüacionada nos estudos sobre o tema. Fala-se hoje em juventude como uma experiência plural e multifacetada, marcada por condição de classe, gênero, etnia, possibilidade (ou não) de ingresso no mundo do trabalho formal. Alguns estudos, entre tantas produções, ao evidenciar a existência dessas diferenças na contemporaneidade, sinalizam para os altos índices de homicídio[2], para os indicadores de exclusão do sistema de ensino regular, para as estatísticas do protagonismo desses jovens no cenário da violência nas grandes cidades brasileiras e para as limitações de suas inclusões no mercado de trabalho formal.

Há uma realidade que insiste em não apresentar outras cores, adornadas em terras paridas na mestiçagem. Excluídos de sua condição de cidadania, de uma formação adequada às exigências do mercado de trabalho, os jovens são levados desde cedo ao trabalho precário[3] ou à inserção no mercado do tráfico de drogas, uma alternativa efêmera para essa população que, quando envolvida, pode ter como desfecho a prisão ou a morte prematura. É uma produção de jovens pobres marcados pela violência, negligência e transgressão aos seus mais elementares direitos. 
Diante desse contexto, contempla-se aqui um olhar que recai sobre o processo constituição da formação profissional no Brasil em que aspectos de ordem econômica e política vão desenhando um perfil de trabalhador frente aos paradigmas que vêm definindo na atualidade o cenário econômico do país, forjado, inclusive e historicamente, por diferentes rostos de juventude. Recai sobre o jovem pobre uma concepção de trabalho e de educação que reafirma os lugares sociais desses sujeitos na dinâmica do capital.

\section{A EMERGÊNCIA DAS CORPORAÇÕES DE OFÍCIO: DA COLÔNIA AO IMPÉRIO}

Entender os sentidos da formação profissional no Brasil exige um olhar caleidoscópico que permita recuperar a dualidade histórica presente no sistema educacional brasileiro. É preciso assinalar que desde o Brasil-Colônia, trabalho e educação, exploração e analfabetismo, estiveram intrinsecamente a serviço do modelo econômico agrárioexportador e dependente (RIBEIRO, 1987). A educação destinada ao trabalhador apresentava características distintas daquela oferecida aos filhos da elite, sendo esta última de fundo abstrato, distante do mundo e da realidade, priorizando o ensino superior e deixando ao abandono a educação primária, já que os filhos das famílias ricas podiam receber um ensino individualizado junto aos preceptores ou serem enviadas aos colégios internos.

Desde a fase jesuítica na educação colonial o acesso ao saber ler, escrever e contar era destinado a uma pequena camada da população - a dos filhos dos donos de engenho-deaçúcar. A política colonizadora, escravista e patriarcal, excluía da escola o índio, o negro e a grande maioria das mulheres, produzindo uma ampla gama de analfabetos. Através das domesticações a população pouco a pouco foi sendo submetida às determinações oriundas das camadas dominantes da sociedade colonial (FREIRE, 1989). A divisão social do trabalho[4] estabelecia desde a colônia as distâncias entre os proprietários e os nãoproprietários dos meios de produção. Se nos engenhos-de-açúcar as domesticações já eram produzidas da senzala a casa-grande, elas também se fizeram presentes sobre a mão-de-obra assalariada e branca, já emergente no auge do regime de produção com base escravista. Os primeiros ofícios presentes no período colonial deram origem a organização da construção civil no Brasil[5] (VALLADARES, 1981).

Sem o intuito de esgotar o debate acerca dos indícios do ensino profissionalizante no período colonial, é preciso destacar a presença do trabalho artesanal organizado predominantemente com base em corporações de ofício. O termo "ofício" permitia diferentes apreensões de sentido. Poderia significar desde um conjunto de práticas que caracterizavam uma profissão, passando também por um conjunto de praticantes de uma mesma atividade produtiva, além de designar o termo corporação que abrangeria mais de um oficio ou profissão (CUNHA, 1978). Desde os engenhos, a olaria e a carpintaria empregavam a mão-de-obra assalariada. E os ofícios desenvolvidos pelos oleiros e carpinteiros exigia que seus aprendizes demonstrassem uma certa competência técnica para a aprendizagem, do ponto de vista da força física, atenção e habilidade para executar os serviços, além de exigir lealdade ao dono do engenho e ao seu capital.

É lúcido lembrar que nos colégios jesuítas os ofícios ligados à construção civil também se fizeram presentes e foram intensificados com 0 advento da mineração e 0 desenvolvimento de núcleos urbanos na colônia dedicados ao comércio no séc. XVII. O surgimento da mineração produziu o florescimento dos ofícios de carpintaria, serviços de pedreiro, olaria e pintura, visto que empreendiam a construção e a manutenção de igrejas, altares, peças sacras em madeira, tetos, etc. Se dentro dos engenhos a submissão se demonstrava pela lealdade ao patrão, no ciclo da mineração, o trabalho assalariado envolvido com as belas-artes se encontrava ligado a certos padrões de beleza e arte predominantemente difundidos pelos católicos conservadores. Sobre a questão da lealdade, é pertinente a análise de Teresa Sales (1994) ao afirmar que esse sentimento de sujeição do escravo ao senhor-de-engenho é a mais antiga expressão da cultura da dádiva na medida em que irá forjar os alicerces de uma cultura política onde a cidadania não 
passa de uma concessão que mantém e alimenta as raízes da desigualdade social na cultura política brasileira[6].

A despeito do Brasil Império, a vinda da família real portuguesa produziu expressivas mudanças especialmente nas cidades do Rio de Janeiro, Vila Rica, Salvador e Recife, estando, portanto, diretamente ligadas às demandas administrativas produzidas pela corte. Também se destacam as mudanças econômicas e políticas desencadeadas pela ruptura do pacto colonial, marcadamente pela abertura dos portos e a revogação do alvará que impedia a instalação de manufaturas no Brasil. Essas medidas ampliam a dependência econômica do Brasil ao governo britânico, mas sinalizam passos sugestivos rumo à independência em relação ao poder imperial português.

A mudança política em 1822 com a proclamação da independência do Brasil não gera uma transformação na estrutura social centrada na manutenção dos privilégios dos grandes proprietários rurais e no trabalho escravo. As inovações de ordem cultural com a criação da Imprensa Régia (1808), a implantação da Biblioteca Nacional, do Jardim Botânico e do Museu Real (a partir de 1810); a chegada da Missão cultural francesa (1816) foram ações expressivas no panorama cultural da época na cidade do Rio de Janeiro. São criadas nesse contexto as academias da Marinha (1808) e a Real Militar (1810), os Arsenais de Guerra da Marinha (1824) e do Exército (1832), intrinsecamente ligados a uma cultura da ordem, da civilidade.

É interessante mencionar que a construção naval propiciou a formação de carpinteiros, cavoqueiros (responsáveis pelo corte de pedra em bruto), calafates, pedreiros, pintores e canteiros, responsáveis pelo talho de pedra (VALLADARES, 1981). O trabalho escravo era utilizado no séc. XVIII nos arsenais da Marinha que estavam funcionando na Bahia, no Pará e no Rio de Janeiro.

A escola primária já era desde suas origens na colônia o lugar dos excluídos. O futuro dos jovens artífices era marcado pelo ingresso nos arsenais de guerra. O ensino dos ofícios era feito nos arsenais da Marinha para a aprendizagem de menores como aprendizes, tendo sido regulamentada tal prática a partir de 1857, pelo regulamento que ditava as normas de funcionamento das Companhias de Aprendizes Menores dos Arsenais da Marinha.

É importante destacar que a aprendizagem técnica dos artífices tinha caráter de caridade pública "destinada a amparar os desvalidos". Nesse sentido os jovens aprendizes precisavam "(...) ser necessariamente órfãos, indigentes, expostos da Santa Casa de Misericórdia ou filhos de pais reconhecidamente pobres" (CUNHA, 1978, p. 3-4).

Para exemplificar a organização desses centros de formação de artífices pode-se analisar as características da Casa dos Educandos Artífices do Pará, criada em 1840. O sistema de ensino compreendia uma formação básica elementar, geralmente oferecida pela manhã e a aprendizagem dos ofícios propriamente à tarde nos próprios locais de produção: 0 arsenal da Marinha, o arsenal de Guerra, o cais e o hospital. Na escola se começava pelas "aulas de primeiras letras", onde era oferecida a alfabetização dos artífices. Era preciso começar pela alfabetização já que de um lado não havia nas províncias um sistema de ensino que os atendesse e, de outro lado, em função da condição socialmente desprivilegiada dos alunos, que não podiam arcar com o ensino oferecido por preceptores. Da aprendizagem das primeiras letras, o mundo do trabalho era o destino do jovem pobre, órfão e desvalido. Começa nesses espaços as primeiras práticas de ensino profissional no Brasil. Nasce aí a irremediável desqualificação da relação trabalho-educação. Subliminarmente aos conteúdos curriculares de desenho, escultura, aritmética, noções gerais de álgebra, geometria e mecânica aplicada às artes os alunos aprendiam a conhecer o preconceito como deixa transparecer o discurso do Presidente da Província do Maranhão, João Antônio de Miranda, na inauguração da Casa de Artífices do Maranhão na qual os alunos deveriam receber "muito rigor" na aprendizagem. 
Um edifício, dirigido por um hábil, receberá os moços pobres, que lhe forem oferecidos, ou escolhidos dentre os recrutados pelos respectivos juízes e órgãos. Ali serão conservados e, mantidos debaixo de ordem militar, receberão instrução de primeiras letras, e princípios religiosos na primeira parte do dia, e se dirigirão ao arsenal, obras públicas e particulares, a fim de serem competentemente instruídos naqueles ofícios para que tivessem propensão (CUNHA, 1978).

Vale lembrar que não se enfatizava no seio da sociedade da época uma idéia de ser jovem, no limite aparecia à condição de estudante (especialmente os filhos da elite) que se preparavam para assumir outro papel socialmente colocado na vida adulta. No caso dos jovens pobres ao contrário da já prejudicada condição de estudante era imposto a condição de trabalhador, o que lhes recaia muito precocemente o ingresso na vida adulta.

Ainda em meados do séc. XIX, expande-se a produção cafeeira diante da crise da produção do açúcar e algodão, incrementando as exportações e mantendo as bases econômicas da aristocracia rural. Em 1870 é significativa a substituição da mão-de-obra escrava pelo trabalho supostamente assalariado de imigrantes, o que contribui dentre outros fatores para enfraquecer os alicerces da já abalada monarquia.

Se a aprendizagem nas corporações de ofício constituía o espaço de aprendizagem dos jovens artífices no início do Brasil-Colônia, no séc. XIX, no Império a instrução oferecida pelas províncias nas Casas de Educandos Artífices seria um registro exemplar das práticas dirigidas ao jovem pobre que visava controlar, refrear as paixões, os "vícios" da juventude. Nessa trilha, além dos educandários espalhados pelo país, foi criado em 1866, após muitas discussões sobre a validade "(...) do ensino e instrução nas classes inferiores da sociedade", uma escola noturna de instrução primária de adultos, com uma função moralizadora. Na época os argumentos da criação ou não da escola noturna eram de fundo moral já que pela instrução os homens "(...) resistem mais vantajosamente ao arrastamento dos vícios e das paixões e (...) curvam-se também obedientes ao cumprimento dos deveres que a sociedade lhes impõe" (CUNHA, 1979, p. 39).

Assim, pela educação destinava-se às camadas pobres a submissão aos desígnios de uma vida fadada à obediência. A escola noturna a ser oferecida como uma pré-formação para os cursos ligados à indústria já ia, pela via ideológica, determinando a posição desses alunos (que já eram trabalhadores, inclusive artífices da construção civil no horário diurno).

A escola noturna de instrução primária para adultos não teve boa acolhida de início, apesar de terem sido feito anúncios e do próprio diretor ter ido às oficinas e fábricas à cata de alunos. O motivo desse desinteresse estava relacionado, de um lado, a vergonha do analfabeto em se apresentar de público e, de outro, porque se realizassem o curso não ficariam isentos de serem recrutados para o serviço militar junto à guarda nacional, privilégio concedido apenas aos estudantes das escolas superiores e secundárias públicas. Então, "para que estudar?", perguntavam-se eles. Como a escola manteve-se vazia por dois anos, aventou-se inclusive a possibilidade de se "(...) obrigar os operários que não soubessem ler a freqüentar a escola noturna", exigir "regulamentação do trabalho dos aprendizes, obrigando-os a freqüentá-la", além de se cogitar também a possibilidade de se "proibir o trabalho industrial para o escravo" (CUNHA, 1971, p. 39). Essa proposta retratava o espírito do ensino a ser oferecido e o claro desinteresse dos operários pela alfabetização, talvez em função de que aprender a ler e a escrever não se constituía numa exigência fundamental para a aprendizagem de trabalho que realizavam, mas muito mais uma nova obrigação a ser cumprida sem sentido e nem valor do ponto de vista social e político na perspectiva desses sujeitos.

Através da educação no Brasil-Império, garantiu-se as relações de produção e, portanto, a sobrevivência do modo de produção escravista e o analfabetismo. No caso das corporações de ofício o controle das relações de produção se dava pela aprendizagem dos ofícios, isto é, pelo monopólio, tanto político como do próprio saber, determinado e restrito 
aos seus pares de irmandade. Aos pobres nos centros urbanos emergentes destinava-se 0 mundo do trabalho. A educação, de um modo geral, em concordância com o pensamento católico-conservador dominante e com o modo de produção escravista, enfatizava o ensino superior e delegava o ensino elementar, secundário e profissionalizante a uma completa desarticulação (CUNHA, 1978). À Corte, a partir do Decreto-Lei estabelecido em 1834 (que vai perdurar em toda a Primeira República), cabia legislar sobre o ensino superior e às províncias, organizar a educação elementar e secundária. Essa dualidade de sistemas ampliava cada vez mais o fosso entre a educação destinada à elite e a educação do povo. A mentalidade escravocrata que seguirá presente no período republicano irá sedimentar essa visão negativa do trabalho destinado aos pobres. A condição juvenil e de classe sofrerão com esse enquadramento sócio-cultural.

\section{A FORMAÇÃO PROFISSIONAL NO PERÍODO REPUBLICANO: DA LEGISLAÇÃO À CONFORMAÇÃO}

Paulatinamente a isso o modo de produção escravista foi dando lugar a novas relações de produção. Em fins do Império e início da República a economia cafeeira, o surto de industrialização promovido especialmente pelo Barão de Mauá, a presença do imigrante como força de trabalho livre gerando o aparecimento de novos extratos sociais e a abolição da escravatura, em 1888, foram marcantes para a passagem do modelo agrárioexportador-dependente e consolidação do modelo agrário-comercial-exportadordependente (RIBEIRO, 1991). Assim, garantia-se até o fim da Primeira República, em 1930, a consolidação do capitalismo no Brasil de forma definitiva.

$\mathrm{Na}$ República a ação interferidora dos capitais externos se agudiza e o Brasil começou a integrar-se a dinâmica do processo de capitalismo dependente. Produzir expansão quantitativa da educação e, portanto, atingir os anseios populares estava fora de cogitação e o debate sobre a expansão da educação ficou arrefecido até o início da primeira década do séc. XX. O ensino profissional dirigido aos pobres e desafortunados é estruturado a partir do Decreto 7.566, de 23 de setembro de 1909 e estabelecia o ensino profissional gratuito em 20 escolas de aprendizes artífices em diferentes estados da federação. Notese que essa medida propositiva acerca do ensino nacional foi uma exceção no contexto da República, já que o Ato Adicional à Constituição de 1834 estabelecia uma dualidade de sistemas de ensino. Caberia às assembléias provinciais legislar e organizar seus sistemas de ensino de nível primário e médio, e ao governo central definir igualmente os ensino primário, médio e superior, mas, exclusivamente no município Neutro. $\mathrm{O}$ ato Adicional de 1834 vigorou por uma boa parte da República, gerando a legalização de percursos de escolarização diferenciados pela descentralização do ensino, já que caberia aos estados e municípios também definir o ensino primário profissional. A criação das escolas de aprendizes artífices, em 1909, será o germe para a emergência das escolas técnicas federais.

Sobre tal aspecto, Kuenzer (1999) denomina de dualidade estrutural a essa bifurcação histórica dos sistemas de ensino no Brasil. As trajetórias educacionais diferenciadas. Para os filhos dos trabalhadores além do curso primário era possível realizar o curso rural e o curso profissionalizante. No nível ginasial poderiam realizar, exclusivamente, cursos profissionalizantes: o normal, o técnico comercial e o técnico agrícola. Nesse contexto essas modalidades educativas não davam ingresso ao curso superior. Aos filhos das elites era destinado o ensino primário e a seguir o ensino propedêutico, voltado para o acesso ao ensino superior, com subáreas profissionalizantes. Desse modo, a educação brasileira no início da República reafirma a separação entre os que devem pensar e os que devem executar, estabelecendo uma educação dirigida aos que devem exercer funções instrumentais e os que devem exercer uma função acadêmica, reproduzindo no âmbito educativo a separação entre capital e trabalho, conforme o paradigma taylorismo-fordismo, isto é da cisão entre aqueles que de um lado exercem funções de execução e, de outro, aqueles que exercem atividades de planejamento e supervisão (KUENZER, 1999). 
A década de 1930 trará novos elementos ao debate sobre a formação profissional que precisam ser contextualizados. A quebra da Bolsa de Nova lorque e a superprodução do café no Brasil ocorridas no contexto da Revolução de 1930 foram exigindo a passagem progressiva de um modelo econômico voltado para a exportação (que não era mais possível de ser realizado) para a satisfação do consumo no mercado interno.

A crise econômica contribuiu para o surgimento de um novo modelo econômico implantado de 1930 a 1964: o de substituição de importações (ROMMANELI, 1989). Se a revolução de 1930 produziu mudanças significativas no modelo econômico, do ponto de vista político também gerou um rearranjo da sociedade, permitindo que pelo afastamento inicial da oligarquia agro-exportadora, os grupos ligados aos tecnocratas, aos militares e aos empresários industriais pudessem exercitar o poder. Getúlio Vargas foi empossado na presidência, à princípio provisoriamente de 1930 a 1937, e a seguir se impôs à nação no chamado Estado Novo, de 1937 a 1945. Foi a partir do Governo Vargas que o Estado passou cada vez mais a assumir um papel intervencionista na economia, isto é, voltado para o desenvolvimento, assentando as bases para a implantação da indústria pesada no país.

Vargas fez uso de grande habilidade política na permanente tentativa de conquista dos diferentes setores da sociedade pelo chamado populismo-trabalhismo, tendo feito uso ora de táticas repressivas para conter o movimento operário, ora por meio da cooptação dos líderes reformadores e a decretação de benefícios sociais como salário mínimo, férias, apoio à gestante, dentre outros. Logo após a instalação do Governo Provisório, Vargas criou o Ministério do Trabalho, que tinha características corporativas, fazendo concessões que visavam a satisfação das exigências populares diante das questões sociais.

Nesse contexto a formação profissional permanece dualista. Na década de 1940 a política econômica favorecia ao protecionismo da burguesia industrial, delegando ao operariado uma política de salários baixos. Também se intensifica o processo de migração interna da população. Os trabalhadores rurais expulsos de suas terras iam para as grandes cidades em busca de melhores condições de vida e vendiam a sua força de trabalho a qualquer preço. Visivelmente se multiplicava a desigualdade que se alimentava da fome e do trabalho de muitos. A isso se chama desenvolvimento e em seu nome se governa. Nesse paralelo há nas cidades uma intensificação das diferenciações profissionais e amplia-se o número de ramos profissionais, levando a uma maior oferta da rede escolar para atender aos diferentes ramos profissionais que se multiplicam. É lúcido destacar que a qualificação técnico-profissional foi à alternativa proposta por Vargas para tentar controlar o processo migratório acima mencionado ao visar conter o clamor social, levando ao filho dos trabalhadores uma profissão (GUIRALDELLI JÚNIOR, 1990). Assim, o modelo econômico passou a ser implementado, mantendo as escolas dirigidas aos filhos das elites e ampliando a oferta de escolas dirigidas ao ensino técnico-profissionalizante, como meio de preparação de mão-de-obra para a indústria e o comércio, além de escolas rurais. A instrução primária permaneceu a não ser atendida numa política nacional até após o Estado Novo.

A Carta Constitucional outorgada pelo Estado Novo estabelecia que o maior dever do Estado seria o oferecimento do ensino pré-vocacional e profissional destinado às classes menos favorecidas a ser cumprido com o apoio das indústrias e sindicatos econômicos. A ênfase nesses aspectos não era fortuita: pelo oferecimento de uma educação técnicoprofissional, no meio urbano e rural, estrategicamente combatia-se tanto os problemas dos "inadaptados sociais", submetendo-os ao mundo do trabalho, como também às idéias bolcheviques. A educação passou a ser, portanto, um instrumento de manutenção e defesa da ordem social vigente, como meio de difusão do Estado Novo, "do culto à Pátria e das tradições", ligada ao binômio "educação-segurança" (GUIRALDELLI JR, 1990; PAIVA, 1987; ARRUDA \& CALDEIRA, 1986).

A preocupação referente ao ensino técnico-profissionalizante gerou a criação, SENAI 
(1942), do SENAC (1946) e das Leis Orgânicas do Ensino, também chamadas de Reformas Capanema, concernentes ao ensino industrial pelo Decreto $\mathrm{n} .94 .073$ de 30/01/1942 e do ensino técnico-comercial pelo Decreto $n .^{\circ} 6.141$ de 28/12/1943, sem ao menos ter sido organizado objetivamente o ensino primário no país. Em 1942 também são criadas as escolas técnicas de artes e ofícios, germinadas em 1909. Essas leis oficializaram a estrutura escolar, do primário ao ensino superior, sendo que o ensino secundário, normal e industrial permitia o acesso ao ensino superior na mesma área, e o ensino comercial e agrícola resumia-se ao ensino primário e técnico na mesma área. Também ratifica-se nesse conjunto as iniciativas públicas e privadas diante das demandas postas pelo crescimento econômico fundado no paradigma fordista-taylorista.

Confirma-se, de novo, um ensino bifurcado e seletivo, um verdadeiro dualismo educacional, ratificando os destinos escolares diferenciados para os jovens pobres e os jovens ricos. É bom assinalar que a lei Orgânica do Ensino Primário só se efetivou em 1946, após a saída (temporária) de Vargas que durante o seu governo criou uma legislação estruturando o ensino-técnico e profissionalizante sem, contudo, resolver os problemas da educação básica de qualidade no país. O surgimento dessas instituições e dos cursos profissionalizantes estava vinculada a uma necessidade de redefinição de importação de pessoal técnico qualificado. A Segunda Guerra Mundial incentivou essa demanda, visto que não era possível manter a importação de técnicos do mesmo modo que não era possível manter a importação de produtos não-duráveis (ROMANELLI, 1989). Essa indústria de bens não-duráveis levou às primeiras indústrias de base, que permitiram, por exemplo, a produção de aço, energia, ambas exigindo, cada vez mais, tecnologia e equipamentos avançados. A criação da indústria de base preparou, por sua vez, o sustentáculo para o aparecimento da indústria de bens de consumo duráveis (automóveis, eletrodomésticos, etc.). A segunda não pode existir sem a primeira e todas as duas demandam "know how" e equipamentos sofisticados. Mas como obtê-los num país que não investia maciçamente em educação, saúde e pesquisa universitária, vivendo ainda, ao final da década de 1950, em tentativas de combate ao analfabetismo? No Brasil, desde antes do Governo Kubitschek, mas mais fortemente a partir dele, ao invés de se investir em tecnologia de ponta, a partir da elevação de quadros técnicos no país, pelo oferecimento de uma educação de qualidade para toda a população, optou-se pela importação de tecnologia. De 1955 a 1960, com o apoio do Governo JK e, posteriormente através de uma política desenvolvida pelos governos militares, de 1964 em diante, incentivou-se a entrada de multinacionais no país.

O Governo JK, sob a influência da ideologia produzida com o apoio do Instituto Superior de Estudos Brasileiros (ISEB), instalou o Nacionalismo-desenvolvimentista. Para Silvia Manfredi (1981), trata-se de um sistema de idéias e concepções em que implicitamente a aceitação do modelo de desenvolvimento sócio-econômico, nos parâmetros capitalistas seja orientada para o atendimento dos interesses nacionais, levando em consideração todas as classes e grupos de uma sociedade entendida essa última como um sistema autônomo. Essa ideologia, aliada às idéias desenvolvidas em torno da economia da educação e do aparato técnico-burocrático que se formava, começou a defender a idéia de que a educação deveria ser um pré-investimento, formador de contingentes de mão-deobra, exigido para o atendimento ao processo de desenvolvimento industrial que ia sendo constituído pela internacionalização da economia com a entrada das multinacionais no país.

O Governo JK gerou uma febre pela educação, sem a qual, segundo ele, o Brasil não poderia ser um "país modernizado", enfatizando o ensino técnico-profissionalizante e a educação para o trabalho. Essa valorização da educação profissionalizante encontra ressonância na intensidade das mudanças ocorridas no mundo do trabalho. $O$ crescimento do setor secundário e terciário e, conseqüentemente, a validação de saberes oriundos do mundo das experiências, para além do mundo acadêmico. Nesse contexto é promulgada a Lei de Diretrizes e Bases da Educação Nacional (Lei 4.024/61) que reconhece a 
articulação entre ensino profissional e ensino regular e produz a equivalência entre os cursos profissionalizantes e os propedêuticos em função da continuidade dos estudos. Nessa mesma perspectiva, o Senai e o Senac organizam seus cursos, em condições de equiparação legal aos níveis de ensino fundamental e médio (KUENZER, 1999) Apesar disso, o sistema de ensino permanecia, apesar dessas iniciativas, altamente elitista e antidemocrático, à semelhança de seus antecessores, Dutra e Vargas.

O período compreendido entre 1962 a 1964, segundo Otávio lanni (1977), significou o auge das crises econômicas e políticas, decorrentes da combinação de modelos distintos: o primeiro voltado para as exportações de produtos, o de substituição de importações e o ligado ao desenvolvimento autônomo que eclodiram num imenso processo inflacionário, numa sociedade economicamente dependente. No bojo dessa crise geradora de tensões entre assalariados e as classes detentoras dos meios de produção, os grupos e partidos de esquerda e de movimentos produzidos pelas entidades estudantis uniram suas forças, visando uma política de ampliação das bases populares de sustentação dos grupos no poder. Os movimentos populares engendrados na sociedade civil, especialmente em torno de campanhas em prol da alfabetização e de conscientização popular, além de legitimarem a ideologia do Nacionalismo-desenvolvimentista colaboraram na formação de quadros de mão-de-obra qualificada e a luta em prol da superação do analfabetismo esteve sempre associada com as reformas estruturais da sociedade (e não isoladamente) a serviço da ultrapassagem de uma situação de país subdesenvolvido.

A ação dos movimentos populares engendrados pela sociedade civil foi respondida com a imposição da Ditadura Militar, iniciada em 1964. O Brasil passou, abertamente a partir de 1964 a adotar uma política de exportação relegando a uma posição de abandono a produção de artigos necessários à população. De 1964 a 1985 houve um crescimento exponencial da dívida externa de 3 para 105 bilhões de dólares, somados a picos inflacionários de 70 a mais de 200\%; inclusive, com recursos destinados à educação despencando de $12 \%$ para $4 \%$ ao ano. Vale ainda ressaltar que tal movimento golpista ao marcar a história brasileira a partir da montagem de um Estado policial, reafirma a existência de uma sociedade dual, desigual e excludente.

O Estado Militar impõe uma nova fase do desenvolvimento do modelo econômico, designado pelo processo de internacionalização da economia em prol da hegemonia do capital financeiro no lugar do nacionalismo-desenvolvimentista. Novamente o crescimento econômico a todo custo para o ajustamento do Brasil a essa nova ordem e ingresso do país no bloco do Primeiro Mundo gerou uma demanda pela qualificação de mão-de-obra técnica. Caberia adequar à educação brasileira a esse tipo de desenvolvimento. Nesse período os governos tiveram uma política de incremento com subsídios e incentivos fiscais a grandes empresas, em detrimento das pequenas, aumentando o contingente de desempregados e a inflação. Com isso, as expectativas das camadas populares voltaramse para o sistema educacional. Em outras palavras, a educação seria a "salvação" de todos os problemas e o caminho para a ascensão e equalização social, servindo como freio amortecedor de reivindicações grupais e sucedâneas das demandas salariais. A política educacional do regime militar vai pautar-se ainda, do ponto de vista teórico, na economia da educação de cunho liberal, fundada na teoria do capital humano. Ela buscava estabelecer uma relação direta, imediata e mesmo de subordinação da educação à produção.

A elaboração da política educacional aparece de modo mais evidente na reforma do ensino médio, em pleno "milagre econômico" e do Governo Médici, em 1971, através da reformulação da Lei de Diretrizes e Bases da Educação (Lei 5692/71). A nova lei apresenta dois pontos fundamentais: a extensão da escolaridade obrigatória, compreendendo agora todo o denominado ensino fundamental e a generalização compulsória do ensino profissionalizante no nível médio. As duas determinações visam conter ou absorver temporariamente a força de trabalho "supérflua", contribuindo para a 
regulação do mercado de trabalho e contenção das demandas pelo acesso à educação de nível superior, pela profissionalização obrigatória o que gera impõe uma significativa redução da educação geral, em detrimento da educação especial nos currículos escolares oferecidos à população.

As expectativas frustradas tanto em relação ao milagre econômico como pelas dificuldades de sua implementação fizeram com que se abandonasse a profissionalização compulsória. O Parecer 75/76, regulamentado posteriormente pela Lei 7.044/82 retirou além da obrigatoriedade da profissionalização em nível secundário, a expressão, no corpo do texto, da "qualificação para o trabalho" por "preparação para o trabalho", admitindo, portanto, a idéia de que o sistema educacional não dispunha das condições para a profissionalização efetiva. Para Acácia Kuenzer (1999), essas legislações normatizaram um novo avanço conservador, pois reafirmaram o lugar da escola como espaço para os já incluídos nos benefícios da produção e do consumo de bens materiais e culturais, já que a escola retoma o dualismo estrutural e consagra o taylorismo-fordista como princípio educativo.

As mudanças nas estruturas produtivas somadas àquelas produzidas nas próprias economias capitalistas centrais têm afetado há séculos as exigências para o mercado de trabalho (sofisticando a formação qualificação educacional necessárias ao trabalho), dilapidando os direitos trabalhistas, as lutas sindicais ampliando o desemprego, dentre outras transformações sociais geram a emergência de uma "nova pobreza" (LOPES, 1994). Esse quadro desde fins dos anos 1970 começou a se fazer sentir nos países periféricos, como o Brasil. A "diferenciação dos pobres" leva a considerar o desaparecimento de qualquer sinal de submissão, como o produzido pela cultura da dádiva, porque:

É uma exclusão daqueles que antes eram parte ou que tinham expectativas realistas de virem a ser parte daquela sociedade, por serem dotados das características educacionais (alfabetização, alguns anos de primário) e de semi-qualificação antes suficientes e agora não mais, para entrarem nos setores modernos da economia. (LOPES, 1994, p. 40)

As três últimas décadas do séc. XX foram marcadas por uma imagem de crise das sociedades contemporâneas. DUBET (2001) aponta que as desigualdades multiplicaramse e não se reduzem ao berço ou a posição de classe, mas são decorrentes de um conjunto complexo de fatores. Dentre esses fatores podemos assinalar a homogeneização social diante das transformações produzidas na estrutura social pelo alinhamento dos modos de vida em torno de normas definidas pelas classes médias e pelo consumo, concentração da pobreza à vida nos guetos e reforço dos processos de estigmatização social; segmentação e pulverização dos mercados de trabalho (terceirização, interinicidade, estágios, dispositivos de apoio social, trabalho à domicílio, dependendo das necessidades econômicas, do sexo, da idade, do capital escolar, da origem étnica: mudanças nas estruturas e nas relações de classe das sociedades industriais marcadas pela ação competitiva dos setores econômicos atuantes a nível internacional e, também, nas estratégias protecionistas que garantem seu estatuto por influência política como os funcionários, agricultores subvencionados, ambos atuando para terceirizar os custos e aumento da precarização dos excluídos desses quadro e incluídos subalternamente no jogo.

Diante disso surge, não apenas uma "nova pobreza" já destacada no texto, mas nos termos de Dubet (2001) uma "multiplicação das desigualdades" em relação, por exemplo, ao aumento da feminilização da população ativa, que engendra diferenças salariais nas diferenças de emprego e renda[7]; as desigualdades étnicas, chegando em alguns países europeus a uma progressiva integração dos filhos de infratores e, ao mesmo tempo, forte segregação pela instalação de zonas de exílio étnico nos bairros pobres e, conseqüentemente surgimento de minorias étnicas; aos jovens pobres, onde o elemento etário e de classe contribui como fator de desigualdade pelo desemprego, inclusão forçada 
na lógica do capital com salários diferenciados. No Brasil os jovens pobres são introduzidos prematuramente no trabalho, como afirma Pochmann no Jornal O Globo (18/04/2004), o país:

(...) parece insistir na afirmação de políticas ultrapassadas de condenação do jovem ao mercado de trabalho, sobretudo aqueles na fase etária mais precoce e de menor escolaridade (...) De cada 10 jovens de classe média e alta, 9 estudam, enquanto somente 4 estudam a cada 10 jovens pobres, sendo 3 fora da respectiva série escolar. Mesmo que o país viesse a encontrar uma situação de pleno emprego, os jovens filhos de pais pobres ficariam no andar de baixo, enquanto os filhos das classes médias e alta no andar de uma hierarquia ocupacional, reproduzindo recorrentemente o padrão execrado de desigualdade de renda. (POCHMANN, Márcio. $O$ Globo, 18/04/2004, Opinião, p. 7)

\section{A FORMAÇÃO PROFISSIONAL NO CONTEXTO DA NOVA LDB}

Embora a diversidade juvenil esteja presente em todas as classes sociais, tais aspectos indicam, além do caráter não homogêneo, para diferentes modos de ser e estar jovem em nossa sociedade que, historicamente, vem modelando e fabricando a cisão entre o trabalho intelectual e o manual, conforme mencionado no corpo do texto.

Nesse campo da dualidade, sabe-se que a composição da economia brasileira alterou sensivelmente ao longo do século $X X$, à medida em que a sociedade passou a não constituir apenas agroexportador, mas começou a dar os primeiros passos rumo à industrialização, redefinindo, conseqüentemente, a estrutura da divisão social do trabalho.

Refletindo essa tendência dominante, tinha-se a formação dos que necessitavam trabalhar, produzir os meios de existência, dando-se no próprio processo de trabalho, ao passo que a formação dos que não necessitavam produzir os meios de vida, se dava fora do trabalho, em um espaço e tempo próprios, assumindo contraditoriamente o caráter de sistema de aperfeiçoamento e reciclagem, dissociado do sistema educacional.

No cenário atual e com relação às oportunidades de inserção no mercado de trabalho, mesmo considerando-se que o trabalho para os jovens pobres se constitua numa das poucas oportunidades de mobilidade social, há na divisão do trabalho uma reprodução do tipo de ocupação direcionada a esta parcela da juventude. Ocupações que afetam, expressivamente, os que possuem pouca escolaridade, baixa qualificação, diante das "(...) vagas de menor remuneração disponíveis, quase sempre conjugadas com posições de subordinação no interior da hierarquia no trabalho" (POCHMANN, 2004, p. 231).

A partir dos anos de 1990, período do ajuste neoliberal no Brasil[8], e consonante ao processo de reestruturação produtiva e do avanço tecnológico, a educação profissional adquire novos contornos ao exigir, e com maior impacto para os jovens que se encontram na condição mencionada acima, um conhecimento mais aprofundado do processo de produção. Tarefas repetidas e parceladas vão sendo substituídas por uma nova configuração na estrutura do mercado de trabalho que solicita um novo perfil de trabalhador, para todos os setores da economia. Agora as exigências voltam-se para as habilidades e competências individuais que permitam aos trabalhadores adaptar-se à produção flexível. Pode-se destacar dentre algumas:

(...) a capacidade de comunicar-se adequadamente, através do domínio dos códigos e linguagens incorporando, além da língua portuguesa, a língua estrangeira e as novas formas trazidas pela semiótica; (...) a capacidade de comprometer-se com o trabalho, entendido em sua forma mais ampla de construção do homem e da sociedade, através da responsabilidade, da crítica, da criatividade. (KUENZER, 1999, p. 129)

Sobre este novo paradigma e segundo Ferreti (1997, p. 229), o que se observa de fato é: 
(...) a desqualificação do antigo trabalhador para atender às novas exigências produtivas. Mas, por outro lado, descortina as possibilidades de requalificação desencadeadas pelas próprias características inovadoras do paradigma que passa a orientar a produção (e também, em boa parte, os serviços).

No bojo dessas transformações, há uma tendência de reformulação nas propostas de educação básica, com forte impacto no ensino profissional (FERRETI, 1997). Capitaneadas por organismos internacionais e com forte expressão do Banco Mundial, tais reformas educacionais passam a objetivar e a adequar o sistema educacional as novas demandas da economia, como se pode observar no corpo teórico da atual Lei de Diretrizes e Bases da Educação Nacional (Lei 9.394/1996).

Aqui a educação se reafirma como o único instrumento, em resposta à pobreza, propiciador para o desenvolvimento econômico e produtivo. Nesse véu de esperanças que se propõe "integrador", restaria apenas a escola redimensionar sua função integradora, na medida em que o "(...) desenho das políticas educacionais deveria orientar-se para garantir a transmissão diferenciada de competências flexíveis que habilitem os indivíduos a lutar nos exigentes mercados laborais pelos poucos empregos disponíveis" (GENTILLI, 2002, p. 89). Assim, o que se assenta e se germina nesse cenário é o sujeito flexível, necessário e produtivo ao capital (HARVEY, 1994), mas gerador de distintas conseqüências quando o foco passa a ser, em especial, o jovem pobre. Baixa remuneração, excessivas jornadas de trabalho, dificuldade para conciliar trabalho e escola, altas taxas de desemprego, aliada às exigências do mercado, e, evocando à exclusão, uma relação de dissonância entre o que o mercado[9] solicita e o que a educação básica oferece.

Sob o imperativo da flexibilidade, da habilidade, da competência etc., detecta-se a manutenção de uma perspectiva instrumentalista dominante. Na realidade, a idéia de qualificação geral e abstrata ao invés de contribuir para a ampliação da capacidade crítica dos trabalhadores, em especial para os jovens, constitui-se numa falácia de liberdade, atrelada aos interesses do capital. Na tentativa de corresponder a tal paradigma, tem-se, no bojo da atual LDB[10] e no contexto da globalização de todos os setores da vida social, as elites responsáveis pela gestão político-administrativa do país rearticulando seus interesses, através de alianças com parceiros internacionais, ao pretender situar o Brasil a partir de uma ordem mundial desenhada por um modelo neoliberal (SEVERINO, 2003).

Trata-se, certamente, de um rejuvenescimento da teoria do capital humano, na medida em que a defesa da necessidade de qualificação do trabalhador, associada à ênfase na educação básica, na construção de sujeitos polivalentes, encontra-se intrinsecamente associada às perspectivas neoconservadoras de ajuste econômico-social e educacionais frente às novas exigências do mercado de trabalho (FRIGOTTO, 2003).

Nesse sentido, o processo de enxugamento do Estado no campo social e na retração dos direitos de trabalho reflete uma política econômica em prol do ajustamento à globalização e ao capital internacional, e não comprometida com uma educação voltada para os interesses da classe trabalhadora, já que as "(...) novas tecnologias ao mesmo tempo em que aumentam a necessidade qualitativa do trabalho vivo, diminuem à necessidade quantitativa do mesmo" (FRIGOTTO, 2003, p. 153).

Alguns indícios apontam para determinadas conseqüências desse modelo: o reflexo da precarização nas relações de trabalho, para não citar o aumento da desigualdade social (ANTUNES, 2003). Sobre os jovens pobres, alguns dados indicam que a maioria trabalha sem carteira assinada e se constitui vítima do subemprego. Somente $41,4 \%$ possuem empregos assalariados, alerta Pochmann (2004). Com relação à taxa de desemprego, a mesma corresponde a $26,2 \%$ quando comparada a jovens pertencentes a classes média e alta, cuja taxa é de 11,6\%. Quando o olhar recai sobre níveis de renda e escolaridade, os números frios da estatística revelam e reforçam as condições diferenciadas de ser jovem. 
Dos pobres, $38,1 \%$ estudam, enquanto para os jovens ricos inativos, ela é de $80 \%$ (POCHMANN, 2004).

Assim, ao mesmo tempo em que se pensa qual ocupação é destinada à juventude pobre, tal correlação com o tipo de escola não pode, também, ser desprezada. As diferenças entre a teoria da escola nos cursos de forma geral e as exigências do mercado de trabalho acabam refletindo o papel da escola no processo de formação da classe trabalhadora (KUENZER, 1999). Pondo à parte o ensino propedêutico, regular, o que se tem, como regra geral, é uma escola cujo desempenho não expressa e nem possibilita ao jovem pobre sua inserção numa cidadania[11] plena.

$\mathrm{Na}$ atualidade e a despeito de programas de formação profissional, desenvolvidos por ações governamentais e em parceria como organizações não governamentais[12], tem-se uma expressiva parcela do ensino no país cabendo às empresas que, assumindo a forma de escolas profissionalizantes, passam a se constituir num sistema paralelo e independente da escola formal, conforme evidenciado a partir da década de 1940. Ressalta-se, por outro lado, características específicas de uma linguagem que definia os modos de produção neste período, conforme já evidenciado, em comparação com o paradigma de produção atual.

No contexto da produção atual onde se exige um novo perfil de trabalhador, assiste-se, na tentativa de articular educação básica e formação técnico-profissional, ao dilema posto por essa integralidade na medida em que uma série de desafios poderiam, na articulação entre escola formal e formação profissional, produzir conhecimentos frente às atuais demandas do emprego assalariado. Assim, a reforma do ensino profissional "(...) levada à efeito pelo Decreto 2.208/97 e pela nova concepção de ensino médio, repõe no cenário da educação brasileira a dualidade estrutural tal como ocorria antes de 1961, com a quebra de equivalência" (KUENZER, 1999, p. 134).

A questão que se coloca, portanto, é que numa sociedade dividida em classes, o sistema educacional não pode ser considerado como um espaço de neutralidade, em menor ou maior grau de contradição, estará difundindo um determinado projeto hegemônico. Com relação à escola e sobre os impactos da reestruturação produtiva, Kuenzer (2002, p. 68) afirma que esta dimensão "(...) tem demonstrado uma face perversa, servindo a escola de instância de seleção prévia, notadamente de classe social, para escolher os mais 'educáveis', e, portanto, mais adequados às finalidades do processo produtivo".

Tal leitura pode ser entendida a partir da prevalência de jovens, aqui reporta-se à idéia, mais uma vez, de classe, que são conduzidos a cursos técnicos ou profissionalizantes. Estes corroboram, certamente, para reforçar determinadas demandas apresentadas por uma juventude pobre que tenta uma inserção e uma manutenção no mercado de trabalho formal. Aqui a noção de experiência para os jovens é reduzida a vivência[13]. Assim, numa perspectiva politécnica, que aglutina trabalho e formação integral, a formação humana não despreza, numa acepção marxista, o acesso aos conhecimentos de formação geral (artes, música, história, geografia, matemática etc.) e conhecimentos específicos (a partir de áreas de conhecimento científico socialmente elaborado). Aqui os jovens pobres nem de longe se aproximam dessa dimensão, e a experiência é subsumida de seu caráter formativo. Haja vista que a integralidade do homem encontra-se comprometida pela própria divisão do trabalho (MANACORDA, 1991).

Nesse campo de contradições em que a educação se refaz dual, e não perdendo-se de vista algumas reflexões, tem-se o Estado não apenas delegando, mas reforçando para o mercado da educação a responsabilidade pelo processo educacional. Ou seja, se a escola, em específico pública, não contribui para a formação básica da criança e conseqüentemente do jovem, a experiência passaria, a partir de uma vivência, a ser a "galinha dos ovos de ouro" para os que buscam uma primeira atividade.

A participação histórica e precoce de jovens pobres trabalhadores é revelador não apenas 
de como a sociedade brasileira vem se configurando ao longo da sua trajetória, mas do agravamento que potencializa nas famílias pobres a entrada cada vez mais recorrente de seus filhos no trabalho precário, marginal e até em atividades do tráfico de drogas, para compor a renda familiar. Mesmo em atividades onde predomina um mínimo de escolarização e de conhecimentos, tem-se uma relação de incompatibilidade entre trabalho e escola. Uma realidade que impulsiona para os bancos escolares noturnos, braços e corpos juvenis imersos no cansaço, no sono, na concentração inexpressiva e, marcadamente, na ausência de tempo para dedicar-se aos parcos conhecimentos produzidos em sala de aula.

Além dessa realidade, predomina-se uma situação de pobreza que acaba determinando além do ingresso do jovem no trabalho precoce, uma "exclusão moral" da escola formal haja vista uma produção de evasão dos espaços escolares quando os jovens buscam no trabalho alguma forma de rendimento e, por outro lado, uma forma de pertencimento, no sentido proposto por Robert Castel (1998). Frente às atuais exigências posta pelo mercado de trabalho pautadas nas políticas neoliberais, o referido autor alerta para o surgimento de uma nova categoria: a dos desfiliados. Assim na tentativa de explicar as novas formas de exploração e de exclusão do capitalismo que mesmo para os trabalhadores qualificados, a inserção e a manutenção destes no emprego não estará garantida. O que torna, inclusive, essa mesma realidade para a juventude, em especial para os jovens pobres, mais vulneráveis socialmente. Diante desse cenário que os colocam em situação de grande vulnerabilidade, existe o risco concreto destes serem absorvidos, na realidade brasileira, pelos segmentos mais marginalizados do setor informal (POCHMANN, 1998).

\section{CONSIDERAÇÕES FINAIS}

O debate da formação profissional no contexto de algumas pesquisas mencionadas a seguir vem reafirmando, independente do conceito de juventude que estejamos nos debruçando, para a problematização de políticas públicas em torno da juventude pobre. Tais pesquisas apontam para a negação dessa mesma juventude quando enfocamos a noção de classe, bem como a fragilidade e até mesmo ausência das políticas a ela dirigidas. Vale ressaltar, sobre políticas públicas mesmo querendo situá-las como ações de governo, deve-se atentar para o seu caráter complexo, fundadas num terreno arenoso, que não pode simplesmente naturalizar a juventude como um problema social, como sujeitos a serem recuperados a partir de uma lógica de regulação social.

No que concerne à constituição do campo de pesquisas sobre a juventude e trabalho no período de 1980 a 1998, o estudo Juventude e Escolarização - Estado do Conhecimento, coordenado por Marilia Sposito (2002) demonstra existir grande produção de teses e dissertações sobre o tema. A temática central é investigada em mais de $70 \%$ dos estudos que parte da escola para refletir sobre o universo do trabalho e os jovens. E mais, Sposito aponta que a maior contribuição desse campo de estudos reside em analisar a esfera do trabalho a partir do locus da escola e em fazer emergir o sujeito estudante trabalhador, especialmente sob a perspectiva da escola noturna, como propõe o estudo pioneiro de Carvalho (1981). Grosso modo, o conjunto de pesquisas que marcam as décadas de 80 e 90 articula-se em torno dos seguintes sub-temas: o curso noturno e a especificidade do aluno trabalhador; jovens, trabalho e profissionalização; escolha profissional; a produção de significados e valores em relação à temática trabalho e sua interconexão com a educação e; por último, são enfatizados estudos centrados no mundo do trabalho e a presença juvenil.

Os estudos acima apontam para a crise da escola diante da juventude que não encontra muitas alternativas de enfrentamento das desigualdades multiplicadas e a importância de aprofundamento das pesquisas em torno dos jovens pobres e o mundo do trabalho, cuja realidade denuncia a existência de outros dilemas em suas vidas: subemprego, trabalho precário, dentre outros. Desde 2003, os autores do presente texto e pesquisadores da Universidade Federal Fluminense, do Programa de Pós-Graduação em Educação, vêm 
desenvolvendo pesquisas onde o foco de análise dos trabalhos, num sentido amplo, abarca as seguintes temáticas: juventude, educação e trabalho. Numa dimensão micro, cada pesquisa se debruça sobre diferentes matrizes teórico-metodológicas, mas se interpõem a partir do instante que pretendem compreender o universo do jovem pobre, com pouca escolaridade e baixa qualificação, em relação ao futuro, à escola, à família, aos sentidos de pertencimentos, etc.

A primeira pesquisa procura problematizar uma experiência de natureza profissionalizante direcionada a jovens pobres na cidade do Rio de Janeiro, buscando entender a partir do diálogo da experiência com esses sujeitos os sentidos atribuídos por eles a um espaço de formação para o trabalho, e como eles vêm sendo constituídos por tais práticas. A segunda pesquisa dirige seu olhar para analisar os jovens que vivem o bairro popular do Jardim Catarina no município de São Gonçalo, na Região Metropolitana do Rio de Janeiro, especialmente os mundos vividos pelos jovens e suas formas de sociabilidade numa territorialidade transitiva que expressa a crise do trabalho e da escola em tempos de globalização, e de forma subterrânea, a ausência de políticas públicas para a população do bairro em foco.

Em ambos trabalhos alguns dados sugerem a partir das falas com os jovens entrevistados uma certa naturalização em relação à formação profissional em detrimento da escola formal. Ainda em termos preliminares, e como historicamente a relação entre educação e trabalho vem sendo forjada por políticas sociais pautadas na reprodução de um sistema de ensino propedêutico e técnico, numa lógica binária que dissocia a formação profissional do sistema educacional, cuja dualidade define uma sociedade de exclusão, produzindo nos discursos dos jovens uma fala naturalizada onde privilegia-se o trabalho. Trabalho este no sentido muito mais de uma representação que o aproxima à tarefa, à ocupação simplesmente, perdendo-se a dimensão de que o trabalho é uma relação social, ou seja, "(...) a forma mediante a qual o homem produz suas condições de existência, a história, o mundo propriamente humano, (...), o próprio ser humano" (FRIGOTTO, 2003, p. 31).

Neste sentido, vai se produzindo uma linguagem instrument alista de trabalho, a partir de uma perspectiva de trabalho moralizante, utilitarista e individualista, num universo de uma parcela da juventude pobre. Isso não significa que tal representação não abarque outras dimensões da juventude numa sociedade de classes, mas percebê-la como que tal lógica reproduz, como já afirmamos, um discurso e uma prática dual ao separar predominantemente o trabalho intelectual do manual. Ressaltamos, inclusive, que não perdemos a dimensão de perceber que mesmo no trabalho configurado como manual há uma dimensão intelectual que o constitui e coloca o homem também numa relação de produção e de consumo.

\section{REFERÊNCIAS BIBLIOGRÁFICAS}

ITUNES, Ricardo. Os sentidos do trabalho. Ensaio sobre a afirmação e a negação do trabalho. São Paulo: Boitempo Editorial, 2003.

RUDA, Marcos; CALDEIRA, César. Como surgiram as Constituições Brasileiras. Rio de Janeiro: FASE, 1986. NJAMIN, Walter. Obras escolhidas I, Magia e técnica, arte e política. São Paulo: Editora Brasiliense, 1994.

IRVALHO, Célia Pezzolo de. Ensino Noturno: realidade e ilusão. São Paulo: Cortez; Autores Associados, 1984.

ISTEL, Robert. As metamorfoses da questão social. Uma crônica sobre o salário. Petrópolis/RJ: Editora Vozes, 1998.

JNHA, Luiz Antonio. Aspectos sociais da aprendizagem de ofícios manufatureiros no BrasilColônia. In: Fórum Educacional, Rio de Janeiro, 2 (4): 31-65, out./dez., 1978.

JBET, François. As desigualdades multiplicadas. In: Revista Brasileira de Educação, Maio/Jun/Jul/Ago, n.․ 17, 2001. 
RRETI, Celso João. Formação profissional e reforma do ensino técnico no Brasil: Anos 90. In: Educação \& Sociedade, ano XVIII, n.․59, agosto/1997.

IEIRE, Ana Maria Araújo. Analfabetismo no Brasil: da ideologia da interdição do corpo à ideologia nacionalista, ou de como deixar sem ler e escrever desde as Catarinas (Paraguaçu) Felipinas, Madalenas, Anas, Genebras, Apolônias e Graças até os Severinos. São Paulo: Cortez; Brasília: INEP, 1989.

IRRESTER, Viviane. O horror econômico. São Paulo: Editora da Universidade Estadual Paulista, 1997.

IIGOTTO, Gaudêncio. Educação e a Crise do Capitalismo Real. 5. ed. São Paulo: Cortez Editora, 2003.

¿NTILI, Pablo. Educar para o desemprego: a desintegração da promessa integradora. In: FRIGOTTO, Gaudêncio (Org.). Educação e Crise do Trabalho. Perspectivas de Final de Século. 6. ed. São Paulo: Editora Cortez, 2002.

IIRALDELLI JR. Paulo. História da Educação. São Paulo: Cortez, 1990.

HARVEY, David. A condição pós-moderna. São Paulo: Ed. Loyola, 1994.

VNI, Octávio. Estado e planejamento econômico no Brasil (1930-1970). 2. ed. Rio de Janeiro: Civilização Brasileira, 1977.

JNTÃNO, Carlos. Terceiro Setor e Questão Social. Crítica ao padrão emergente de intervenção social. São Paulo: Cortez Editora, 2002.

IENZER, Acácia Zeneida. A reforma do ensino técnico no Brasil e suas conseqüências. In: FERRETI, Celso J.; SILVA JR., João dos Reis; OLIVEIRA, Maria Rita N. S. (Orgs.). Trabalho, formação e currículo: para onde vai a escola? São Paulo: Xamã, 1999.

IPES, Juarez Brandão. A cultura política do mando. Subserviência e nossas populações pobres. In: RBCS, n. -25 , ano 9, junho, 1994.

INACORDA, Mario Alighiero. Marx e a pedagogia moderna. São Paulo: Cortez Editora, 1991.

IVA, Vanilda P. Educação Popular e Educação de Adultos. São Paulo: Loyola, 1987.

RALVA, Angelina. O jovem como modelo cultural. In: Revista Brasileira de Educação. Juventude e contemporaneidade. mai/jun/jul/ago, 1997, ํ5 set/out/nov/dez, 1997, ํㅡ.

ICHMANN, Márcio. Juventude em busca de novos caminhos no Brasil. In: NOVAES, Regina; VANNUCHI, Paulo (Orgs.). Juventude e Sociedade. Trabalho, Educação, Cultura e Participação. São Paulo: Editora Fundação Perseu Abramo, 2004.

3EIRO, Maria Luisa Santos. História da Educação Brasileira. A organização escolar. 11. ed. São Paulo: Cortez Editora, 1991.

JMANELLI, Otaíza de Oliveira. História da Educação no Brasil. 11. ed. Petrópolis: Editora Vozes, 1989.

LES, Teresa. Raízes da Desigualdade Social na Cultura Política Brasileira. In: RBCS, n.ำ 25, ano 9, junho, 1994.

„NTOS, Wanderley Guilherme dos. Cidadania e justiça: a política social na ordem brasileira. 3. ed. Rio de Janeiro: Campus, 1994.

:VERINO, Antonio Joaquim. Os embates da cidadania: ensaio de uma abordagem filosófica da nova LDB. In: BRZEZINSKI, Iria (org.). LDB Interpretada: diversos olhares se entrecruzam. 8. ed. São Paulo: Cortez Editora, 2003.

'OSITO, Marilia et al. Juventude e Escolarização - Estado do Conhecimento. Brasília, INEP, Ação Educativa, 2000. 
LLES, Vera da Silva. Direitos sociais: afinal do que se trata? In: Revista USP, São Paulo (37), 34-45, março/maio, 1998.

ILLADARES, Lícia do Prado (Org.). O processo de trabalho e a formação profissional na construção civil. Rio de Janeiro: Ed. FGV, 1981.

AISELFISZ, Jacobo. Mapa da Violência IV. Rio de Janeiro: UNESCO, Instituto Ayrton Senna, Ministério da Justiça/SEDH, 2004.

\section{* Doutoranda em Educação do Programa de Pós-Graduação da Universidade Federal Fluminense.}

* Doutorando em Educação do Programa de Pós-Graduação da Universidade Federal Fluminense.

[1] Neste trabalho, entende-se juventude como uma categoria social e para compreendêla, é necessário recorrer a forma como os jovens expressam seus comportamentos, gestos, desejos, suas opções de vida, emoções, paixões.

[2] Conforme o Mapa da Violência IV, divulgado pela UNESCO (Organização das Nações Unidas para a Educação, Ciência e Cultura) no dia 07/06/2004, o número de homicídios entre os jovens, na faixa entre 15 e 24 anos, aumentou 88,6\% de 1993 a 2002. No ranking entre os estados, o Rio de Janeiro apresenta o maior número de homicídios entre os jovens: de 73,2 para 118,9 assassinados por cem mil habitantes, ou seja, foram 8.321 mortes para o ano de 2002 (WAISELFISZ, 2002).

[3] Em 2001, segundo o IBGE, através da Pesquisa Nacional por Amostra de Domicílios PNAD, havia no Brasil cerca de 5,5 milhões de crianças e jovens trabalhando. Mais de um milhão deles não freqüentavam a escola e quase $49 \%$ trabalhavam sem remuneração. Com relação à faixa etária entre 15 a 17 anos, do total de 10.306.707 jovens, 3.250.541 estavam exercendo algum tipo de atividade.

[4] Ressalta-se que a concepção de trabalho referida neste artigo busca superar a dimensão abstrata do trabalho enfocando suas expressões hoje demandadas pelo trabalho precário, terceirizado, temporário. Portanto, entendido como processos contraditórios, tanto a educação formal quanto a profissional suscitam reordenamentos diante dos novos desafios postos pelo mercado de trabalho e pelas políticas neoliberais que buscam a privatização dos serviços públicos, com expressiva pressão sobre o campo educacional.

[5] As análises aqui empreendidas dos ofícios e corporações no período colonial têm por base os estudos de Valladares (1981) e Cunha (1978).

[6] O princípio da cultura política da dádiva somente sofrerá uma ruptura no seio da formação social brasileira segundo Sales (1994) a partir do séc. XX, mais precisamente no início dos anos 1960, no momento em que os trabalhadores rurais são expulsos das grandes propriedades. Contudo, Juarez Lopes (1994) afirma que é preciso levar em conta que na virada do séc. XIX para o séc. XX, com o ciclo do café, o ingresso da mão-de-obra migrante, e a abolição da escravatura, inicia-se um expressivo processo de diferenciação social localmente produzida, de dimensões regionais, especialmente entre a área açucareira do Nordeste e a zona cafeeira do Centro-Sul. O que se quer destacar aqui é que a cultura da dádiva, do favorecimento, presente também no Centro-Sul, é um 
fragmento da estrutura social capitalista (LOPES, 1994).

[7] Antunes (2003, p. 108) destaca sobre isso que “(...) a expansão do trabalho feminino tem se verificado sobretudo no trabalho mais precarizado, nos trabalhos em regime de part time, marcados por uma informalidade ainda mais forte, com desníveis salariais ainda mais acentuados em relação aos homens, além de realizar jornadas mais prolongadas".

[8] Segundo Vera Telles (1998, p. 44), a produção da pobreza no Brasil incorpora mais uma dimensão para explicar a "infinitude" da sua existência. Infinitude no sentido do aprofundamento das desigualdades sociais diante de um Estado supostamente democrático em terras brasilis. Sendo assim, na atualidade "(...) a nossa velha e persistente pobreza ganha contemporaneidade e ares de modernidade por conta dos novos excluídos pela reestruturação produtiva. Mas não só por isso: lançando mão dessa ficção regressiva do mercado auto-regulável, nossas elites podem ficar satisfeitas com sua modernidade e dizer, candidamente, que a pobreza é lamentável, porém inevitáveis dados os imperativos da modernização tecnológica em uma economia globalizada".

[9] Um mercado de trabalho errático nas afirmações de Forrester (1997, p. 16) ao produzir trabalhadores que não são contratados com tanta freqüência, e "(...) como vegetam, em particular os jovens, numa vacuidade sem limites, considerada degradante, e como são detestados por isso; ao ver como, a partir daí, a vida os maltrata e como a ajudamos a maltratá-los".

[10] Kuenzer (1999, p. 135) assinala que embora a nova lei assegure a possibilidade de manutenção de cursos de habilitação profissional “(...) que integrem educação geral e formação profissional, o Decreto N. 2.208/97, na prática, inviabilizou esta possibilidade. Da mesma forma, a equivalência entre os cursos de nível médio, gerais e profissionais, conquistada desde a LDB de 1961, desaparece quando o mesmo decreto determina que a continuidade de estudos depende do certificado de conclusão de ensino médio, e os novos cursos profissionais não exigem escolaridade anterior para a realização de cursos de nível básico e médio".

[11] No tocante à questão da cidadania e da sua relação com a pobreza, alguns autores trazem como pano de fundo um modelo de cidadania onde o indivíduo termina por ser subsumido a uma corporação profissional. Destaca-se aqui o que Wanderley Guilherme dos Santos (1994, p. 68-69) denominou de "cidadania regulada", cujas raízes encontramse, não em um código de valores políticos,"(...) mas em um sistema de estratificação ocupacional, e que, ademais, tal sistema de estratificação ocupacional é definido por norma legal (...) O instrumento jurídico comprovante do contrato entre o Estado e a cidadania regulada é a carteira profissional que se torna, em realidade, mais do que uma evidência trabalhista, uma certidão de nascimento cívico". É como se a cidadania, contraditoriamente, sofresse um desvio, ou simplesmente, apresentasse algumas facetas, em específico, num modelo de sociedade capitalista engendrado no plano econômicopolítico-social, particularmente, do Brasil pós-1930.

[12] Segundo Carlos Montaño (2002, p. 15-16), além das ONGs, encontram-se um número significativo de organizações e instituições, sem fins lucrativos (OSFL), filantrópicas, empresas "cidadãs", sujeitos coletivos e individuais, voluntários ou não, que compõem o chamado "terceiro setor". A relevância do debate se faz pertinente por tem-se nos dias atuais, "(...) o isolamento (mediante a 'setorialização' de esferas da sociedade), e a mistificação de uma sociedade civil (definida como 'terceiro setor'), 'popular', homogênea e sem contradições de classes (que em conjunto buscaria o 'bem-comum') e em oposição ao Estado (tido como 'primeiro setor', supostamente burocrático, ineficiente) e ao mercado ('segundo setor'), orientado pela procura do lucro, contribui para facilitar a hegemonia do 
JOVENS POBRES E A EDUCAÇÃO PROFISSIONAL NO CONTEXTO HIST... Página 18 de 18

capital na sociedade".

[13] Nos anos 1930, Walter Benjamin (1994) formulará a noção de vivência (Erlebnis) em oposição à noção de experiência (Erfahrung). Para ele, a vivência não consegue ir além do tempo. A ação se esgota no momento de sua realização, sendo, portanto, finita. Por outro lado, a experiência só pode ser produzida e entendida pelo seu conteúdo histórico. Ela não esquece o passado, pois ele representa o fio condutor para a construção de outro futuro. Portanto, a experiência é coletiva, narrada, pensada e compartilhada para e com os outros sujeitos. 